Obras citadas

Monrós Gaspar, Laura (2011a). Cassandra the Fortune-teller: Prophets, Gipsies and Victorian Burlesque. Bari: Levante Editori.

- ed. y trad. (2011b). Casandra, de Florence Nightingale. Valencia: Institució Alfons el Magnánim.

Antonio Ballesteros GonZÁlez

Rodríguez Richart, José. Dos patrias en el corazón. Estudios sobre la literatura española del exilio. Madrid: Verbum, 2009.

Guerra Civil española. Resistencia. Refugiados. Segregación en las fronteras, deportación a campos de concentración y de exterminio. Persecución y supervivencia clandestina, retorno a la España represiva o reemigración a terceros países. Reúnen estas palabras una de las secuencias definidoras del exilio de 1939, que constituye el ámbito de referencia de los trabajos reunidos en Dos patrias en el corazón, volumen que viene avalado por la autoridad que el Profesor José Rodríguez Richart ostenta en el ámbito del estudio del exilio literario, ejercida desde su Cátedra de la Universidad de Säarbrucken (Alemania). En once capítulos, el presente libro ofrece una panorámica de trabajos publicados en monografías colectivas de ámbito internacional y en revistas de alto impacto tan prestigiosas como Anthropos, Anales de la Literatura Española Contemporánea, Boletín de la Biblioteca de Menéndez Pelayo o Hispanorama. Estos artículos permiten valorar la relevancia de una trayectoria que ha ofrecido líneas de reflexión de gran calado sobre la pluralidad de las memorias colectivas e individuales del exilio, una diáspora protagonizada por republicanos, socialistas, anarquistas, comunistas, personas sin filiación política, figuras de posición acomodada, civiles y militares, hombres y mujeres de a pie, ancianos y menores de edad, colectivos diversos que fueron acogidos por otros países de la Europa occidental, de la Unión Soviética o del continente americano. Entre las múltiples virtudes de Dos patrias en el corazón está la de ser una impecable selección que ha conseguido integrar la perspectiva vivencial y la estética practicada por los autores estudiados con las corrientes filológicas en boga en el momento de elaborar cada ensayo. Se logra con ello poner de relieve parte de las aportaciones que, desde el ámbito académico, se han venido haciendo en el campo a lo largo de varias décadas.

Abre el volumen la ponderación del valor histórico de una importante muestra de literatura española escrita en campos de trabajo, de concentración y de exterminio en Alemania y Francia. Protagoniza su primer capítulo la obra del autor de Viviré con su nombre, morirá con el mío, Jorge Semprún, internado en Buchenwald y emblema internacional de la lucha contra el nazismo en títulos como Aquel domingo o La escritura o la vida. Otra de las enseñas literarias escogidas para transmitir un testimonio homologable es Max Aub, autor de Campo francés y de Diario de Djelfa, en los que examina con intención documental lo sucedido en el universo concentracionario, una galería de horrores que conoció Aub de primera mano y que se vio acrecentada en su estancia los campos penitenciarios de África del Norte. De este autor, refugiado en España al desencadenarse la Primera Guerra Mundial, se ofrece detalle de sus círculos de allegados, su ideología, el peso de su contribución literaria, poética y teatral, su afición por los movimientos estéticos franceses y su afecto declarado 
por unos estados como Francia y España que representaron en un sentido la utopía de libertades y el atractivo cultural que veneró, pero que también conoció en su posible vertiente xenófoba de corte antisemita. Ocupa la atención del ensayo siguiente un segundo exilio iniciado por el autor en Francia y su deportación a varios campos de concentración, como da cuenta en Morir por cerrar los ojos o Una historia cualquiera, antes de huir rumbo a México. Lo biográfico, lo artístico y lo paraliterario se aúnan a la hora de analizar un teatro que fue desarraigado a la fuerza del público potencial para el que fue escrito.

La recuperación de esta literatura de indudable valor histórico pone un broche de especial relevancia al centrarse en el estudio imagológico de la literatura española sobre Alemania y Francia, tanto en temáticas relacionadas con la Primera y la Segunda Guerra Mundial como en las migraciones de españoles a diversos países europeos durante los años cincuenta. El Profesor Rodríguez Richart presta atención, además de a escritores reconocidos, a las experiencias de los trabajadores españoles desplazados a tierras germanas, ya que, más allá de su valor estético en estos casos ocupa su interés lo revelador de sus testimonios en el orden biográfico y sociológico.

Las obras cuyo valor documental ensalza el volumen reseñado son también La forja de un rebelde y Valor y miedo, de Arturo Barea, muestra de la visión del autor en los ámbitos religioso, militar, económico, político e institucional, auténticas crónicas de la España sometida a la guerra, la vigilancia y la censura. A continuación es centro de interés de otro de los ensayos reunidos en este volumen el currículum profesional de Alejandro Casona, desde su Asturias natal y su residencia murciana hasta sus primeros contactos en
Madrid con escritores de prestigio como Marquina, Hernández Catá, Baroja, ValleInclán o Machado. Su experiencia como Inspector de Enseñanza, como impulsor de las Misiones Pedagógicas, como ensayista, conferenciante, escritor de guiones de cine o renovador de la escena española de los años treinta a través de su teatro poético, dan paso a la memoria de sus veinticinco años de exilio en Argentina, con un capítulo dedicado al estudio de la correspondencia mantenida con Max Aub, exiliado en México en el tiempo en el que mantuvieron este intercambio epistolar.

Dos patrias en el corazón tiene asimismo el valor añadido de que sus páginas han sido escritas por un maestro filólogo en lengua española y alemana, con dominio además del catalán y del valenciano, competencia lingüística privilegiada que le ha permitido realizar la semblanza y el análisis crítico de autores que a menudo no venían siendo incluidos en los cánones del exilio republicano de 1939. Es el caso del diario épico Las Hogueras del Pertús, de Álvaro de Orriols, una obra poco conocida y sin embargo un relato de la evacuación de Cataluña representativo del éxodo de miles de personas durante la Guerra Civil, que documenta la diferente actitud entre la entonces hostil Francia oficial y la humanidad de la Francia popular. Es también el caso de Agustí Bartra i Lleonart -autor, entre otras, de Cristo de 200.000 brazos - y de Pere Vives i Clavé -una de cuyas obras más destacadas es Cartes des dels camps de concentración-, apresado en el campo austríaco de Mauthausen. A lo narrativo y lo documental frente a lo poético y lo lírico de las creaciones del jiennense Manuel Andújar -creador de Saint Cyprien, plage... Campo de concentración- se dedica también un espacio específico en este libro. 
El único artículo del volumen que se centra en un destierro que no tuvo lugar durante la Guerra civil española lo protagoniza la poesía del exilio de Miguel de Unamuno durante su expatriación, con emblemas como De Fuerteventura a $\mathrm{Pa}$ rís... o Romancero del destierro. Leemos en ellos los versos de un intelectual que continuó toda su vida en la lucha política, y de quien se examina su biografía sociopolítica, su socialismo y republicanismo, su oposición a la monarquía y a la dictadura, su confinamiento a Fuerteventura y su autoexilio en Francia. Cierra el volumen un ensayo dedicado al teatro de Pedro Salinas, con un estudio comparado de las piezas La cabeza de Medusa, La isla del tesoro y La estratosfera, con comentarios específicos sobre el madrileñismo de una poética de sello arnichesco.

La panorámica ofrecida por Dos patrias en el corazón viene firmada por un gran investigador en la materia, con una experiencia profesional que le ha hecho valedor de reputado especialista en sacar a la luz y en visibilizar las creaciones de profesionales de la poesía, el teatro, la novela, el ensayo o la pedagogía, pero también la voz de figuras anónimas con mucho que revelar. Fue nombrado por ello Caballero de la Real Orden de Isabel La Católica. Esta contribución a la ampliación del canon literario reseñado es el resultado de la intensa labor desarrollada por el Profesor Rodríguez Richart en la primera línea del estudio de la comunidad creadora del exilio español.

\section{RAQUel García-PASCUAL}

Romera Castillo, José, Pautas para la investigación del teatro español y sus puestas en escena, Madrid, UNED, 2012, $462 \mathrm{pp}$.
Este volumen es, por encima de todo, un manual para investigadores, ya que recoge modelos y pautas teóricas de análisis de un fenómeno tan complejo y poliédrico como es el teatro en su doble vertiente textual y escénica. Su autor, José Romera Castillo, lleva años dedicándose a la Semiótica en general, y más aún a la Semiótica teatral, lo cual le ha convertido en un pionero en territorio español. Resulta casi abrumador recordar aquí todas sus actividades: fundador de la Asociación Española de Semiótica, creador de la revista Signa y del Centro de Investigación de Semiótica Literaria, Teatral y Nuevas Tecnologías, promotor de premios y becas de investigación, editor de textos teatrales, organizador, junto al profesor Francisco Gutiérrez Carbajo, de los Seminarios Internacionales celebrados rigurosamente en junio, sobre todo en la sede de la UNED de Madrid (este año ha tenido lugar el vigésimo segundo), donde no solo se encuentran profesores de distintas latitudes, sino que además en ellos participan algunos de los dramaturgos y directores teatrales más destacados de la escena peninsular, y cuyas Actas se publican puntualmente en la prestigiosa editorial Visor. Sin olvidar que en los últimos años a esta iniciativa se ha unido el Centro de Documentación Teatral, dirigido por Julio Huélamo, bajo cuya supervisión se ha creado una ambiciosa revista digital, Don Galán (en la que desempeña un papel destacado el autor de estas Pautas), que no esconde sus intenciones de convertirse en referente para todo el ámbito de lengua española. En definitiva, nada ni nadie que pertenezca al «fascinante mundo de Talía» queda excluido del entramado teatral que se aglutina en torno al proyecto de Romera Castillo, caso que ya en sí mismo resulta ejemplar y si se nos permite decirlo esperanzador. 